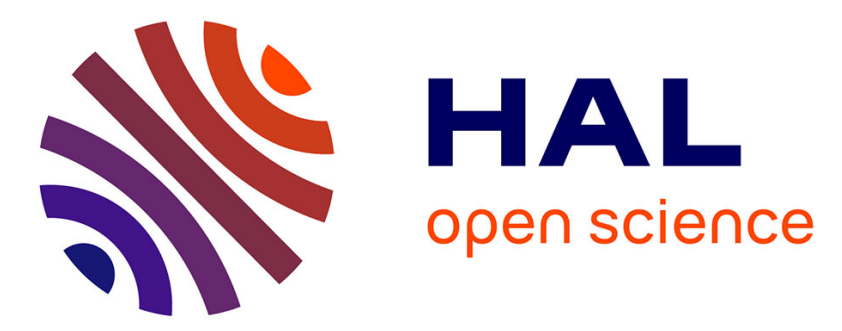

\title{
Trace element partitioning during partial melting of carbonated eclogites
}

\author{
Tahar Hammouda, Bertrand N. Moine, J.L. Devidal, C. Vincent
}

\section{To cite this version:}

Tahar Hammouda, Bertrand N. Moine, J.L. Devidal, C. Vincent. Trace element partitioning during partial melting of carbonated eclogites. Physics of the Earth and Planetary Interiors, 2009, 174 (1-4), pp.60. 10.1016/j.pepi.2008.06.009 . hal-00533031

\section{HAL Id: hal-00533031 \\ https://hal.science/hal-00533031}

Submitted on 5 Nov 2010

HAL is a multi-disciplinary open access archive for the deposit and dissemination of scientific research documents, whether they are published or not. The documents may come from teaching and research institutions in France or abroad, or from public or private research centers.
L'archive ouverte pluridisciplinaire HAL, est destinée au dépôt et à la diffusion de documents scientifiques de niveau recherche, publiés ou non, émanant des établissements d'enseignement et de recherche français ou étrangers, des laboratoires publics ou privés. 


\section{Accepted Manuscript}

Title: Trace element partitioning during partial melting of carbonated eclogites

Authors: T. Hammouda, B.N. Moine, J.L. Devidal, C. Vincent

PII: $\quad$ S0031-9201(08)00128-3

DOI: $\quad$ doi:10.1016/j.pepi.2008.06.009

Reference: $\quad$ PEPI 4971

To appear in: $\quad$ Physics of the Earth and Planetary Interiors

Received date: $\quad 8-11-2007$

Revised date: $\quad 14-4-2008$

Accepted date: $\quad 13-6-2008$

Please cite this article as: Hammouda, T., Moine, B.N., Devidal, J.L., Vincent, C., Trace element partitioning during partial melting of carbonated eclogites, Physics of the Earth and Planetary Interiors (2007), doi:10.1016/j.pepi.2008.06.009

This is a PDF file of an unedited manuscript that has been accepted for publication. As a service to our customers we are providing this early version of the manuscript. The manuscript will undergo copyediting, typesetting, and review of the resulting proof before it is published in its final form. Please note that during the production process errors may be discovered which could affect the content, and all legal disclaimers that apply to the journal pertain. 


\section{Abstract:}

Crystal / melt partition coefficients for Sr, U, and three Rare Earth Elements ( $\mathrm{La}, \mathrm{Gd}, \mathrm{Yb}$ ) have been measured during melting of carbonated eclogitic composition in the 4 - 7 GPa range. The experiments were conducted in a multi-anvil apparatus. Trace element concentrations were determined using electron microprobe and laser ablation ICP-MS in some cases. The obtained clinopyroxene / melt partition coefficients are very low whether the melt is silicate or carbonate in nature. This feature is due to $\mathrm{Na}$ presence and high vacancy concentration in the clinopyroxene. On the other hand, garnet / melt partition coefficients fall at the lower limit of or are slighly lower than litterature data dealing with carbonate melt-bearing systems.

We note that clinopyroxene / carbonated melt partition coefficient values for the Rare Earth Elements cannot be modelled using the lattice strain model. The reasons for the discrepancy lie on assumptions about melt structure as well as clinopyroxene solution model. In the latter case, high $\mathrm{Na}$ combined with high vacancy concentration precludes ideal mixing on octahedral sites to be a valid assumption. Taking charge balance on clinopyroxene crystallographic sites does not solve the discrepancy, suggesting that melt structure can be important. Garnet / melt partition coefficients can be predicted but we note a possible influence of the melt structure. The newly obtained partition coefficients have been used to test some simple models of mantle metasomatism. 
1 Trace element partitioning during partial melting of carbonated eclogites.

2

3 T. Hammouda ${ }^{1}$, B.N. Moine ${ }^{2}$, J.L. Devidal ${ }^{1}$, C. Vincent ${ }^{1}$

4

$5{ }^{1}$ Laboratoire Magmas et Volcans - UMR6524

6 Observatoire de Physique du Globe de Clermont Ferrand

7 Clermont Universités-CNRS-IRD

85 , rue Kessler

963038 Clermont-Ferrand cedex

10 FRANCE

11

$12{ }^{2}$ Laboratoire Magmas et Volcans - UMR6524

13 Université Jean Monnet

14 23, rue du Dr. P. Michelon

1542023 Saint-Etienne

16 FRANCE

17 


\section{Introduction}

Although they occur rarely on the Earth's surface, carbonatitic magmas are important for our understanding of deep-seated processes such as the geodynamic cycle of volatiles and

trace element redistribution. The nature of the carbon source as well as the petrological environment where carbonatitic magma genesis takes place has been the subject of numerous experimental studies focusing either on peridotitic (Wyllie and Huang, 1976 ; Eggler, 1978 ; Wallace and Green, 1988 ; Falloon and Green, 1989 ; White and Wyllie, 1992 ; Dalton and Presnall, 1998) or on eclogitic sources (Hammouda, 2003 ; Dasgupta et al., 2004, Yaxley and Brey, 2004). All authors showed that carbonatitic magmas could be generated in the mantle at $\mathrm{P}$ and $\mathrm{T}$ conditions that can vary from those of the upper mantle to those of the transition zone.

Erupted carbonatites are often enriched in incompatible elements (e.g. Nelson et al., 1988 ; Wooley and Kempe, 1989). Carbon-rich liquids are also highly mobile in the mantle (Watson et al. ; 1990 ; Hammouda and Laporte, 2000), which gives them a high potential for modifying lithologies they might encounter during their transport in the Earth's mantle (Green and Wallace, 1988). The combination of high mobility and incompatible enrichment prompted experimental studies aiming at determining trace element partition coefficients between carbonatitic melts and silicate minerals (Brenan and Watson, 1991 ; Sweeney et al., 1992, 1995 ; Klemme et al., 1995 ; Blundy and Dalton, 2000) in order to model trace element incorporation in the melt at its source as well as element deposition during melt-rock interaction. Most of the previous studies focused on minerals present in peridotites. However, recent studies considered eclogitic environment as a potential source for carbonated liquids

39 (Hammouda, 2003 ; Dasgupta et al., 2004, Yaxley and Brey, 2004). In this perspective, it 40 appears that trace element partitioning data considering eclogitic mineralogy (omphacite, 41 calcic garnet, rutile) are lacking. The aim of the present study is to present experimental data 
relevant to carbonatitic melt genesis in eclogitic environment. For this purpose, we have performed partial melting experiments on trace element doped carbonated eclogitic material at $\mathrm{P}$ and $\mathrm{T}$ conditions where earlier investigations showed that carbonate and / or silicate melt can be produced. Run products have been analyzed by electron microprobe and laser ablation ICP-MS for trace elements and partition coefficients have been determined.

\section{Experiments and analyses}

\subsection{Experimental protocol}

All experiments have been performed in multi-anvil apparatus. Starting material was a trace element doped mixture of basaltic glass and natural calcium carbonate ( $9: 1$ in weight). In order to introduce the trace elements, we mixed a synthetic basaltic glass (OTB issued from the same batch as material used in Hammouda, 2003) with carbonate containing the trace element mixture. Introduction of the latter was achieved by dry mixing of trace element oxides to the carbonate using successive dilution steps. This procedure which was at first intended for electron microprobe analysis yielded two batches of starting mixes that were doped with approximately 200 and $2000 \mathrm{ppm} \mathrm{La}, \mathrm{Gd}, \mathrm{Yb}, \mathrm{U}, \mathrm{Pb}, \mathrm{Sr}$ expressed as oxides. Samples were loaded in $\mathrm{Au}_{80} \mathrm{Pd}_{20}$ capsules which were shut by arc welding.

High-pressure experiments were performed in the octahedral multi-anvil apparatus of the Laboratoire Magmas et Volcans in Clermont-Ferrand using a Walker (1990) module and following the procedure described in Hammouda (2003). High-pressure assemblies consisted of Cr-doped $\mathrm{MgO}$ octahedra and used pyrophyllite gaskets. All experiments were performed with an 18/11 assembly (octahedra side-length $=18 \mathrm{~mm}$; WC cube truncation edge-length $=$ $11 \mathrm{~mm}$ ) calibrated against the $\alpha-\gamma$ transition in the $\mathrm{Fe}_{2} \mathrm{SiO}_{4}$ system (Morishima et al., 1994) and the coesite-stishovite transition (Akaogi et al., 1995). The recorded pressures of the experiments are believed to be accurate within $0.5 \mathrm{GPa}$. Heating was achieved using stepped 
$67 \mathrm{LaCrO}_{3}$ tubular furnaces. The samples were placed at the center of the furnace, inside $\mathrm{MgO}$ sleeves to prevent contact between the furnace and the gold capsules. Zirconia sleeves were placed between furnaces and octahedra to minimize heat-loss. The temperature was read with a $\mathrm{W}_{5} \mathrm{Re}_{95}-\mathrm{W}_{26} \mathrm{Re}_{74}$ thermocouple encased in a mullite sleeve and positioned axially in the assembly, in contact with the top of the sample container. The temperature was monitored using a Eurotherm 900 controller and remained constant within $1{ }^{\circ} \mathrm{C}$ during the course of the experiments. In some cases where the thermocouple failed, temperature was monitored using the value of the electrical output power. No correction for the pressure effect on the thermocouple emf was applied. Each experiment consisted of first raising the pressure to the desired value before heating. Run duration was 20 hours at high temperature (Table 1). This duration was considered sufficient to achieve chemical equilibrium in a system containing melt and crystals at about $1300^{\circ} \mathrm{C}$. For example, Blundy and Dalton (2000) used time series experiments and demonstrated chemical equilibrium at $3 \mathrm{GPa}$ and $1375^{\circ} \mathrm{C}$ in less than 20 hours. The runs were terminated by switching off the power of the furnace, resulting in a temperature drop below $200^{\circ} \mathrm{C}$ in less than 2 seconds. Samples were then slowly decompressed during approximately 12 hours.

\subsection{Electron probe analyses (major and trace elements)}

After recovery, experimental charges were mounted in resin and polished to $1 / 4 \mu \mathrm{m}$ grit using diamond paste. The nature of the phase present and their textural relationships were determined using a scanning electron microscope at Laboratoire Magmas et Volcans. Operating conditions were $15 \mathrm{kV}$ accelerating voltage. Major element compositions were determined with a Cameca SX100 electron microprobe at Laboratoire Magmas et Volcans. Operating conditions were $15 \mathrm{kV}$ accelerating voltage and beam current of $15 \mathrm{nA}$, using a collapsed beam for crystalline phase and defocused beam $(10 \mu \mathrm{m})$ for melt pools. Standards 
used were albite $(\mathrm{Na}, \mathrm{Si}), \mathrm{Al}_{2} \mathrm{O}_{3}(\mathrm{Al}), \mathrm{Fe}_{2} \mathrm{O}_{3}(\mathrm{Fe})$, olivine $(\mathrm{Mg}, \mathrm{Ni})$, wollastonite $(\mathrm{Ca})$, synthetic $\mathrm{MnTiO}_{3}(\mathrm{Mn}, \mathrm{Ti}), \mathrm{Cr}_{2} \mathrm{O}_{3}(\mathrm{Cr})$ and orthoclase $(\mathrm{K})$. Data reduction was performed using the ZAF procedure.

For trace element analyses $(\mathrm{Sr}, \mathrm{U}, \mathrm{Pb}, \mathrm{La}, \mathrm{Gd}$ and $\mathrm{Yb})$ a $25 \mathrm{kV}$ accelerating voltage was used with a $100 \mathrm{nA}$ beam current. The three REE were chosen so as to avoid interferences on the L $\alpha$ fluorescence peaks. Measurements were performed on an LLiF analyzing crystal, using counting times of $100 \mathrm{~s}$ on peak. The three other trace elements were measured on a PET crystal using the L $\alpha$ line of Sr, with counting times of $300 \mathrm{~s}$ and the $\mathrm{M} \beta$ line of $\mathrm{U}$ and $\mathrm{Pb}$, with counting times of 150 s. Standards were $\mathrm{SrSO}_{4}$ for $\mathrm{Sr}, \mathrm{UO}_{2}$ for $\mathrm{U}$, home made synthetic glass for $\mathrm{Pb}$, and NIST standard glasses for REE. Detection limits were calculated following Ancey et al. (1987) and were less than $100 \mathrm{ppm}$ for Sr and REE, 225 ppm for $\mathrm{U}$ and $350 \mathrm{ppm}$ for $\mathrm{Pb}$.

\subsection{Laser ablation ICP-MS analyses}

Trace elements in minerals and glass from experiment \#273 were determined in polished section using a Perkin Elmer Elan 6100 ICP-MS coupled with a femtosecond laser (Pulsar 50 from Amplitude Technologies) at Laboratoire de Modélisation des Transferts Géochimiques (Observatoire Midi Pyrénées, Toulouse-France, Poitrasson et al., 2005). The laser was operated at $800 \mathrm{~nm}$ wavelength with $100 \mu \mathrm{J} /$ pulse energy, $3 \mathrm{~Hz}$ frequency and $50 \mathrm{fs}$ pulse duration. Crater size was 10-15 $\mu \mathrm{m}$ (Fig. 1) and ablation duration was 50-100 s. Ablation was done in pure He atmosphere and the analyte was carried to the ICP torch by a mixture of $\mathrm{He}+\mathrm{Ar}$. Detection limits range from $100 \mathrm{ppb}$ for $\mathrm{U}$ to $10 \mathrm{ppm}$ for Ni. NIST 610 glass standard (values from Norman et al. 1996) was used for calibration of relative sensitivities and each analysis was normalized using $\mathrm{CaO}$ content for clinopyroxene, garnet and melts, determined by electron microprobe. Signal intensity for major and minor elements 
117 was monitored during analysis to make sure that the laser beam kept running within selected 118 mineral grain. Trace-element reductions were done with the GLITTER software (Van 119 Achterberg et al., 2001).

\section{Results}

\subsection{Phase relationships and major element compositions}

Experimental assemblages are given in Table 1 together with run conditions. Run products consist of garnet, clinopyroxene, coesite (at 6 and $7 \mathrm{GPa}$ ) and quenched melt (Figure 1). Electron microprobe analyses (major elements) of run products are given in Table 2. Garnets are calcium-rich whereas clinopyroxenes are sodium rich (omphacite). Additionally, we found that clinopyroxenes contain a large amount of the Ca-eskola compound, a feature that has been pointed out by Pertermann and Hirschmann (2002) in their study on eclogite melting. Mass balance has been performed on the basis of major element compositions determined by electron microprobe. Only experiments \#273 and \#274 could be treated. The others showed strong zoning across the capsule precluding meaningful mass balance.

Two types of melts were found. Up to $6 \mathrm{GPa}$, we found a silicate melt with about 51 $\mathrm{wt} \% \mathrm{SiO}_{2}$ at $4.5 \mathrm{GPa}$ to $40 \mathrm{wt} \% \mathrm{SiO}_{2}$ at $6 \mathrm{GPa}$. The electron probe total ranges from about 92 wt $\%$ at $4.5 \mathrm{GPa}$ to $82 \mathrm{wt} \%$ at $6 \mathrm{GPa}$. Although low total can be anticipated in glass analyses using electron microprobe, the very low total found is partly attributed to dissolved $\mathrm{CO}_{2}$ in the melts. At $7 \mathrm{GPa}$, the melt is purely carbonatitic, with no silicate fraction dissolved. This melt

137 is calcium rich $(\mathrm{Ca} /(\mathrm{Ca}+\mathrm{Fe}+\mathrm{Mg})$ ca. 0.77$)$. These features are consistent with earlier work in

138 the same system (Hammouda, 2003). Melt fraction is lower at $7 \mathrm{GPa}$ (ca. $10 \mathrm{wt} \%$ ) because only carbonate contributes to liquid whereas lower pressure melts (ca. $28 \mathrm{wt} \%$ at $6 \mathrm{GPa}$ ) are composed of a large silicate fraction. 

coefficients and literature data

Table 3 presents trace element concentrations and calculated partition coefficients.

145 Lead could never be detected in the experimental run products. This absence is likely due to 146 dissolution in noble metal capsules. When available (run 273) trace element concentrations 147 obtained by the two techniques (EPMA and LA-ICPMS) are in agreement within 30\% (Fig 148 2a). However, we note a systematic offset, where trace element concentrations obtained by 149 EPMA are always lower than those obtained by LA-ICPMS. In addition, it seems that heavier 150 elements display the largest offset. Important to note, however, is that calculated partition 151 coefficients determined with both techniques agree very well (Fig. 2b). Calculated mineral/melt partition coefficients and comparison with literature data on mineral / carbonated melt partition coefficients are presented in Figure 2a (clinopyroxene) and 2b (garnet). Literature data on trace element partitioning involving carbonatitic melts are available on clinopyroxene (Adam and Green, 2001 ; Blundy and Dalton, 2000 ; Brenan and Watson, 1991 ; Klemme et al., 1995 ; Sweeney et al., 1995, Keshav et al., 2005) and garnet

157 (Adam and Green, 2001; Green et al., 1992 ; Sweeney et al., 1992, 1995). Previous

158 experiments were performed between 1.5 and $6 \mathrm{GPa}$. Analytical techniques included electron 159 microprobe, ion microprobe (SIMS, Blundy and Dalton, 2000), proton probe (PIXE, Green et 160 al., 1992 ; Sweeney et al., 1992, 1995), leaching and mass balance (Brenan and Watson, 161 1991), and laser ablation ICP-MS (Adam and Green, 2001; Klemme et al., 1995; Keshav et 162 al., 2005).

163 For clinopyroxenes, we note that our values are lower by about one order of 164 magnitude when compared with literature data, except for Sr. As will be discussed later, this is likely due to clinopyroxene crystal chemistry. On the other hand, our data for garnet are in 

both $\mathrm{U}$ and $\mathrm{La}$ is satisfactory.

\section{Discussion}

agreement with literature data. This general agreement for garnets is observed whatever the technique used by the previous authors.

When possible, we also calculated clinopyroxene / garnet partition coefficients (Table 3). The $D_{R E E}^{c p x / g t}$ have rather low values, from about 1.5 for La to 0.024 for $\mathrm{Yb}$. We note that the obtained values bear some resemblance to literature data on some Na- and vacancy-rich clinopyroxene and Ca-rich garnet found in mantle eclogites from Roberts Victor kimberlites (Caporuscio and Smyth, 1990 ; Harte and Kirkley, 1997). In particular, the higher the Na in clinopyroxene the lower the REE content while Ca-rich garnet are rather rich in REE.

\subsection{Mass balance and chemical equilibrium}

Run durations (20 hours) have been chosen to favor chemical equilibrium in the samples. In order to check for the validity of our results, mass balance calculations have been performed on two samples where enough data were available. In addition, those calculations were used to discriminate which technique gave more consistent results when discrepancy was noted. The criterion was that mass balance should reproduce the composition of the starting material within $20 \%$. Calculations performed on $\mathrm{Sr}, \mathrm{Gd}, \mathrm{Yb}, \mathrm{La}$ and $\mathrm{U}$ show an overall agreement between computed mass balance based on analyses of experimental samples and initial concentrations in starting material (Table 4). We therefore confirm that experimental samples reached equilibrium. In detail, we note that in the case of sample \#273, ICP-MS data are clearly overestimating true concentration for Gd and $\mathrm{Yb}$, while EPMA data allow to better satisfy mass balance. Strontium mass balance is satisfactory whatever the analytical technique. Concerning La and U, only ICP-MS data are available. Mass balance for 


\subsection{Lattice strain modeling and crystal chemical effects}

Generally, experimentally obtained trace element partition coefficients are fitted using

193 the lattice strain model such as that developed by Wood and Blundy (1997) for REE

194 partitioning between clinopyroxene and silicate melts. The purpose of the lattice strain model 195 is to predict values of unknown trace element partition coefficients using major element 196 compositions of crystals and melts equilibrated at given $\mathrm{P}$ and $\mathrm{T}$ conditions. Here we used the

197 theoretical expressions and compared the predicted values to our experimental results. We 198 preferred this approach, instead of the usual fitting of experimental data found in the

199 literature, because of the small number of elements analyzed in the present investigation.

200 Using Wood and Blundy (1997), one can predict the value of the partition coefficient $D_{i}$ of an 201 element of ionic radius $r_{i}$ as a function of $r_{0}$, the radius of the crystallographic site, $E$, the 202 Young's modulus of the site, and $D_{0}$, the strain-free partition coefficient of a cation having 203 the radius $r_{0}$, with

$$
D_{i}=D_{0} \exp \left(-4 \pi E \mathrm{~N}_{A}\left[\frac{r_{0}}{2}\left(r_{i}-r_{0}\right)^{2}+\frac{1}{3}\left(r_{i}-r_{0}\right)^{3}\right] / R T\right)
$$

205 where $\mathrm{N}_{A}$ is Avogadro's number, $R$, the gas constant and $T$, the temperature in $\mathrm{K}$. In the 206 following, we discuss our results on clinopyroxene using Wood and Blundy (1997) and on garnet, using van Westrenen and Draper (2007) and Draper and van Westrenen (2007).

\section{Pyroxenes}

Following Wood and Blundy (1997) we focused on trivalent Rare Earth Elements. The

211 predicted $D_{i}$ vs. $r_{i}$ relationship is shown on Figure $3 \mathrm{a}$. It can be seen that the predicted 212 partition coefficients are more than one order of magnitude larger than the actual data. This 213 offset is larger than what is expected from Wood and Blundy (1997) model (92\% probability 214 that $D_{i}$ is between 0.63 and 1.59 of the actual value). In order to gain further insight into the 
model vs. data comparison, we have attempted to fit our REE data to the Wood and Blundy

216 expression, keeping in mind that the fit is poorly constrained because we have only three

217 elements. Nevertheless, La, Gd, and $\mathrm{Yb}$ covering almost the whole range of REE radii, we

218 found the attempt worthwhile. The resulting fit is also shown on Figure 3. We note that the 219 difference between the modeled and the fitted lattice strain parameters is essentially on the $D_{0}$

220 value. The value of $D_{0}$ is defined by Wood and Blundy (1997) in the following manner

$D_{0}=\exp \left[\frac{88750-65.644 T+7050 P-770 P^{2}}{R T}\right] \cdot \frac{M g_{\text {melt }}^{\#}}{X_{M g}^{M 1}}$

This expression has been regressed and its coefficients $\left(\Delta H_{T}^{0}, \Delta S_{T}^{0}, \Delta V\right.$, and $\left.\frac{\partial \Delta V}{\partial P}\right)$ have been adjusted for volatile-free silicate melts and vacancy-free clinopyroxenes. That our $D_{0}$ is poorly predicted by the model can be due either to crystal or melt properties. To address the first possibility we used the data of Pertermann and Hirschmann (2002) on vacancy-rich clinopyroxene at $3 \mathrm{GPa}$. The effect of melt properties have been tested using the high pressure data $(6 \mathrm{GPa})$ of $\mathrm{Keshav}$ et al. (2005) on $\mathrm{CaO}-\mathrm{MgO}-\mathrm{Al}_{2} \mathrm{O}_{3}-\mathrm{SiO}_{2}-\mathrm{CO}_{2}$ (kimberlite) system and lower pressure $(2.5 \mathrm{GPa})$ data on carbonatite system by Adam and Green (2001). For all studies, we used the lattice strain model to calculate $D_{0}, r_{0}$, and $E$. The results are added to

Figure 3. Again, we note that $r_{0}$ and $E$ are correctly predicted while calculated $D_{0}$ is larger by a factor 1.7 to 2.1 for vacancy-rich clinopyroxene, by a factor 2.8 to 3.3 in the kimberlite melt case, and by a factor 7.6 for the carbonatite system. As in our samples, the calculated $D_{i}$ values fall outside the range [0.63 - 1.59] times the true values that has been judged acceptable by Wood and Blundy (1997). Since our samples combine both characteristics (i.e. vacancy-rich pyroxenes and carbonated melts), it is easy to understand that the lattice strain model fails to predict our experimental data. wherein the melt consists of pyroxene-like structural units. Rare Earth Element partitioning is 
then described as an equilibrium between a melt and a crystal having the same stoichiometry, i.e., REEMgAlSiO 6 (Eq. 30 in Blundy and Wood, 1997). However, silica undersaturated carbonated melts such as those produced in the present investigation cannot be described in terms of pyroxene-like entities. More likely, REE solubility should be described in terms of carbonated complex because high-pressure studies on carbonate - silicate two-liquid partitioning demonstrated that REE are preferentially partitioned in carbonate melt (Hamilton et al., 1989 ; Wendtland and Harrison, 1979). Consequently, the heats, entropies, and volumes of fusion of pyroxene-like units used in fitting Wood and Blundy's equations are not applicable in our case.

The second reason for discrepancy between the model prediction and our data lies in the presence of vacancies in the pyroxene. The composition-activity model of Wood and Blundy (1997) uses $a_{R E E M g A L S i O_{6}}^{c p x}=X_{R E E}^{M 2} \cdot X_{M g}^{M 1}$ on the assumption of a REE-bearing clinopyroxene having the stoichiometry of $\mathrm{REEMgAlSiO}_{6}$ and ideal mixing on both $\mathrm{M}$ sites. However, in our case, clinopyroxene M2 site has a low mean electrostatic charge $(<+1.5)$ because of the presence of a monovalent cation $(\mathrm{Na})$ and of high vacancy concentration, while the M1 site has a high electrostatic charge $(>+2.5)$ due to the presence of $\mathrm{Al}^{3+}$ associated with the vacancies (Ca-Eskola molecule, $\mathrm{Ca}_{0.5} \square_{0.5} \mathrm{AlSi}_{2} \mathrm{O}_{6}$ ) and not compensated by lower charge on the tetrahedra. This site filling is likely to be unfavorable for $\mathrm{REE}^{3+}$ incorporation in the M2 site and non-ideal mixing associated with short-range order in the clinopyroxene M sites should be anticipated. Wood and Blundy (2001) addressed the effect of electrostatic charge due to cation valence (non ideality) and they proposed a modification for the $\mathrm{D}_{\mathrm{o}}$ expression that takes into account the probability of having a favorable crystallographic site, in terms of charge balance. Although they were mainly interested in CaTs molecule (i.e., tetrahedral $\mathrm{Al}$ coupled to octahedral Al in M1 site) we attempted to model our vacancy-rich clinopyroxenes using their formulation. We found that the predicted $D_{0}$ were slightly lowered as expected for 
264 clinopyroxene with little $\mathrm{Al}^{\mathrm{IV}}$ but never reached our experimental values. We note from Wood 265 and Blundy (2001) that taking into account cation charge changes the $\mathrm{D}_{\mathrm{o}}$ values for trivalent 266 cations by no more than $25 \%$ relative, either increase or decrease, depending on tetrahedral $\mathrm{Al}$ content. Therefore, taking into account cation charge does not reconcile experimental data on carbonated melt-bearing systems with predictions using lattice strain modeling. When applied to Pertermann and Hirschmann's (2002) compositions, Wood and Blundy's (2001) expression increases $\mathrm{D}_{0}$ values because of high $\mathrm{Al}^{\mathrm{IV}}$ contents, resulting in a poorer agreement with experimental values.

\section{Garnet}

Draper and van Westrenen (2007) and van Westrenen and Draper (2007) revised the earlier model of van Westrenen et al. (2001) and developed two predictive models for garnet / melt trivalent trace element partitioning (REE, Y, Sc). Both approaches are compared to our results on REE, on Figure 3b. Overall, it seems that the models satisfactorily predict the measured partition coefficients because the experimental points fall within the range defined by the statistical and thermodynamic models. We note, however, that the predicted $\mathrm{E}$ is too 280 large resulting in impossibility of simultaneously predicting all REE D's with a single model. The $\mathrm{D}_{\mathrm{o}}$ predicted with the statistical model agrees well with the experimentally determined value. Therefore, MREE and HREE can be reproduced but not LREE. On the other hand, the $\mathrm{D}_{\mathrm{o}}$ predicted with the thermodynamic model is higher by a factor of about 50 yielding in poor 284 prediction of MREE and HREE, while measured LREE falls on the predicted value. That the 285 thermodynamic model fails to predict $D_{0}$ accurately suggest that either garnet or melt 286 properties are not well reproduced by the model. Concerning garnet, the critical point is the 287 presence of quadruvalent cations in the octahedral site. Si and Ti were incorporated in the 288 model for E (Young's modulus) by van Westrenen and Draper (2007) but neither the 
thermodynamic nor the statistical model explicitly take into account the majoritic component in $\mathrm{D}_{\mathrm{o}}$ modeling because its effect seemed to be minor. Nevertheless, our garnets are not majoritic and therefore, no compositional effect emanating from garnet is expected. On the other hand, melt composition or structure can be important. van Westrenen and Draper (2007) considered that melt effect is difficult to demonstrate given the available garnet / melt partitioning data. On the other, Draper and van Westrenen (2007) anticipate a potential effect of melt composition and structure in the presence of water. Here, we suggest that carbon presence in the melt could also have an impact on partition coefficients.

\subsection{Effect of melt composition on partition coefficients and liquid/liquid partition coefficients}

Previous studies on carbonate - silicate liquid/liquid partition coefficients have shown that REE partitioning strongly depends upon pressure. At low pressure $(\mathrm{P}<0.1 \mathrm{GPa})$, Veksler et al. (1998) showed that all REE but La partitioned into the silicate melt. Liquid / liquid partition coefficients, $D_{R E E}^{\text {carb } / s i l}$, ranged between $1.33(\mathrm{La})$ to $0.30(\mathrm{Tm})$. Hamilton et al. (1989) studied the effect of pressure, temperature, and melt structure on $D_{R E E}^{\text {carb } / \text { sil }}$. They observed that $D_{L R E E}^{c a r b / s i l}>D_{H R E E}^{c a r b / s i l}$ at all conditions. At low pressure, REE are partitioned in the silicate melt and the trend is reversed at $\mathrm{P}>0.2 \mathrm{GPa}$ for LREE and $\mathrm{P}>0.4 \mathrm{GPa}$ for HREE. According to Hamilton et al. (1989) increasing temperature favors REE partitioning into Na-rich silicate melts but temperature has limited effect in Ca-rich system. Wendlandt and Harrison (1979) showed that REE are preferentially partitioned in carbonate melt at $1300^{\circ} \mathrm{C}$ and 0.5 and 2 GPa.

The present data can be used to discuss the effect of melt composition on REE partitioning. Figure 4 shows that $D_{G d}^{g t / l i q}$ decreases smoothly with pressure for Gd in the $4.5-$ $7 \mathrm{GPa}$ range, while $D_{Y b}^{g t / l i q}$ is constant within error in the $4.5-6 \mathrm{GPa}$ range and decreases 
abruptly between 6 and 7 GPa. Decreasing trends for MREE and HREE have been observed by Draper et al. (2003) for garnet / melt in chondritic system. These authors attributed their observations to the onset of majoritic substitution in garnet. In the present study, we have no evidence for majoritic substitution in garnet. More likely, $\mathrm{D}_{\mathrm{Gd}}$ and $\mathrm{D}_{\mathrm{Yb}}$ evolution between 4.5 and $6 \mathrm{GPa}$ is solely due to pressure effect on garnet bulk modulus and consequently on its Young's modulus (E). Given the form of the pseudo-parabolae that describe trivalent cation partition coefficients in the octahedral site of garnets (e.g. van Westrenen et al., 1999), we can anticipate that HREE will be only slightly affected by E increase because they sit on the maximum of the curve (i.e. HREE effective radii are close to the ideal value corresponding to strain-free substitution). On the other hand, as MREE sit on a descending branch, lower $\mathrm{D}_{\mathrm{REE}}$ can be expected with pressure increase accompanied by higher E values. solely to pressure nor to garnet composition because garnets are almost identical in the 6 and $7 \mathrm{GPa}$ experiments. We must therefore conclude that the change in $D_{Y b}^{g t / m e l t}$ is mainly due to change in liquid composition from silicate to carbonate. Wendlandt and Harrison showed that not only are the REE preferentially partitioned in carbonate melt at high pressure but also that $D_{H R E E}^{\text {carbonat/silicate }}>D_{M R E E}^{\text {carbonate/silicate }}>D_{L R E E}^{\text {carbonate/silicate }}$. The consequence is that $\mathrm{Yb}$ is more retained in 331 the melt when it becomes carbonatitic, a feature that explains the sharp decrease of $D_{Y b}^{g t / m e l t}$ between 6 and $7 \mathrm{GPa}$.

Although the present study was not designed to investigate trace element liquid/liquid 334 partition coefficients, our data allow to discuss the effect of melt nature by considering the 335 composition of silicate melt and coexisting carbonate globules in the lower pressure run (6 $336 \mathrm{GPa} ; 1300^{\circ} \mathrm{C}$ ). If we assume that it is an equilibrium texture, we can calculate the following 337 partition coefficients using electron probe analyses: $D_{S r}^{\text {carb } / \text { sil }}=1.58 ; \quad D_{U}^{\text {carb } / \text { sil }}=1.38$; $D_{L a}^{c a r b / s i l}=1.96 ; D_{G d}^{c a r b / s i l}=1.83 ; D_{Y b}^{c a r b / s i l}=1.69$. We find that $\mathrm{Sr}$ is preferentially partitioned into 
carbonate melt in agreement with previous investigators (Veksler et al., 1998). In the case of REE, we agree with Wendlandt and Harrison (1979) and Hamilton et al. (1989) in that REE are preferentially partitioned in carbonate melt at high pressure. Therefore, this trend appears to be robust at mantle pressure, whatever the melt composition. Almost all previous studies used alkali-rich melt compositions, mainly because the authors were interested in direct comparison with natural melt compositions. In our case, melts are poorer in alkalis, mainly because of the presence of Na-rich clinopyroxene in the experimental assemblages. Nevertheless, high-pressures favor REE partitioning into the carbonate melt.

\section{Implications for mantle metasomatism}

Melts produced by carbonated eclogite melting might be liberated from the slab and interact with surrounding mantle. The processes involved are illustrated in Figure 5 on the basis of REE, Sr and U only. (We are presently lacking information on other elements.) In our models, we considered a starting composition of 90 percent basalt +10 percent carbonated pelagic sediments (in weight). Initial $\mathrm{REE}, \mathrm{Sr}$ and $\mathrm{U}$ concentrations were taken from McDonough and Sun (1989) and Planck and Langmuir (1998) for basalt and sediments, respectively. The trace element spectrum of the starting mixture is shown on Figure 5a. All simulations considered batch-melting hypothesis.

The spectra of melts produced at 6 and $7 \mathrm{GPa}$, are almost identical (Fig. 5a). The contrast in major element composition between melts produced at $6 \mathrm{GPa}$ (silicate) and $7 \mathrm{GPa}$ (carbonate) appears to have limited impact. Main features are enrichment of $80-100$ for the most incompatible elements, and enrichment of slightly less than 10 for HREE, relative to primitive mantle (McDonough and Sun, 1995). HREE fractionation relative to LREE is due to garnet presence in the residue. Positive $\mathrm{U}$ and $\mathrm{Sr}$ anomalies reflect the simulated source characteristics. 
Next we consider two end-member models for a carbonatite melt interacting with

365 peridotite mantle (Figure $5 \mathrm{~b}$ ). In the first case, a low melt fraction (1 wt $\%)$ is simply added to the peridotite. The resulting REE spectra exhibit slight LREE enrichment relative to HREE $\left([\mathrm{La} / \mathrm{Yb}]_{\mathrm{N}}<2\right)$. In the second type of model, we considered large volumes of carbonatitic melt percolating through the mantle and subsequent melt-mineral equilibrium. In this model we used the partition coefficient fitted from the data of Adam and Green (2001) for garnet, and from Blundy and Dalton (2000) for clinopyroxene. The percolated mantle contains 15 wt $\%$ clinopyroxene and $8 \mathrm{wt} \%$ garnet. The calculated REE spectrum exhibits HREE enrichment relative to LREE $\left([\mathrm{La} / \mathrm{Yb}]_{\mathrm{N}}<0.01\right)$ with $[\mathrm{LREE}]_{\mathrm{N}}<1$. Very low $[\mathrm{LREE}]_{\mathrm{N}}$ is due to low values of the clinopyroxene / melt and garnet / melt partition coefficients for the LREE and the assumption of very large volume of percolating melt that leached the mantle. A more plausible scenario is that of infinite mantle reservoir. In that case, the LREE part of the spectrum levels off with values slightly less than 1 .

The third step of the model consists in remelting the mantle region metasomatized by the carbonatitic melt (Figure 5c). One case considers mantle wherein melt has been simply added (melting degree 0.5 and $1.5 \mathrm{wt} \%$ ), whereas the other case (1.5 wt $\%$ melting degree) is for the mantle region equilibrated with the percolating melt. The first model yields a steep pattern with high LREE enrichment relative to HREE ([La/Yb $]_{\mathrm{N}}$ about 40 to $\left.>100\right)$. On the opposite, the second model yields pattern with $[\mathrm{REE}]_{\mathrm{N}}$ in the range $5-10$ exhibiting slight MREE enrichment. This type of spectrum is unknown for natural melts but some alkaline cumulates have been found with similar patterns (Grégoire et al., 1998).

The REE pattern obtained by melting of mantle with simple addition of $1 \mathrm{wt} \%$ carbonated melt has about the same level of HREE enrichment and twice LREE levels when compared to melting of fertile pyrolitic mantle (with $1.5 \mathrm{wt} \%$ melting, Fig. 5c). Our modeled melts bears strong resemblance with those of kimberlite particularly when very small melting 
412 the mantle shows that it possible to create sources whose subsequent melting might yield

degrees are considered. Modeling of trace element patterns of kimberlites has been attempted by Keshav et al. (2005). Those authors modeled melting of a refractory mantle portion mesomatized by silicate melt by $1 \mathrm{wt} \%$ melting and found that similarities with kimberlites could be obtained only after repeated steps of melting and metasomatism. Here we find that a single metasomatic stage is sufficient in order to obtain kimberlite REE signatures.

\section{Conclusions}

We have obtained new partition coefficients values relevant to melting of subducted carbonate-bearing eclogitic composition in the $4-7 \mathrm{GPa}$ range. The nature of Na- and vacancy-rich clinopyroxenes yields very low values for crystal / melt partition coefficients of REE, U, and Sr to a lesser extent, compared to literature data. Garnet / melt partition coefficients fall at the lower limit of literature data dealing with carbonate melt-bearing systems.

Clinopyroxene / carbonated melt partition coefficient values for the Rare Earth Element cannot be modeled using the lattice stain model (Wood and Blundy, 1997) in its current state, mainly because the pyroxene and melt respective solution models differ strongly in the present case. In addition, ideal solution on each octahedral (M) site in Na- and vacancyrich clinopyroxenes might no longer be a valid assumption. Taking into account cation charge budget on octahedral sites (Wood and Blundy, 2001) does not allow reducing the discrepancy significantly. We also find that garnet partition coefficients are not predicted in a satisfactory manner, suggesting that carbonated melts have an effect that is not included in the models in their present state as suspected in the case of water by Draper and van Westrenen (2007). Simple modeling of single stage reaction of melts liberated by carbonated eclogites in liquid bearing strong resemblance with kimberlites, on the basis of REE pattern, mainly. 
Acknowledgements : We thank M. Veschambre for assistance with the electron microprobe and J.-M. Hénot and F. Faure for assistance on the scanning electron microscope. We much appreciated the help from F. Poitrasson and R. Freydier on the laser ablation ICP-MS. Comments by J. Longhi and an anonymous reviewer helped improve the manuscript. Financial support from CNRS-INSU (DyETI program) is acknowledged. The multi-anvil apparatus of Laboratoire Magmas et Volcans is financially supported by the Centre National de la Recherche Scientifique (Instrument National de l'INSU).

\section{References}

Adam, J. and Green, T.H., Experimentally determined partition coefficients for minor and trace elements in peridotite minerals and carbonatitic melt, and their relevance to natural carbonatites, Eur. J. Mineral. 13 (2001) 815-827.

Akaogi, M., Yusa, H., Shiraishi, K., Suzuki, T., Thermodynamic properties of $\alpha$-quartz, coesite, and stishovite and equilibrium phase relations at high pressures and high temperatures, J. Geophys. Res., 100 (1995) 22337-22347.

Ancey, M., Bastenaire, F., Tixier, R., Applications des méthodes statistiques en microanalyse, in F.Maurice, L.Meny, R.Tixier, Microanalyse Microscopie électronique à Balayage, éditions de physique (1987) 323-347.

Blundy, J.D., Dalton, J.A., Experimental comparaison of trace element partitioning between clinopyroxene and melt in carbonate and silicate systems, and implications for mantle metasomatism. Contrib. Mineral. Petrol. 139 (2000) 356-371.

Brenan, J.M., Watson, E.B., Partitioning of trace elements between carbonate melt and clinopyroxene and olivine at mantle P-T conditions. Geochim. Cosmochim. Acta 55 (1991) 2203-2214.

Caporuscio, F.A, Smyth, J.R., trace element crystal chemistry of mantle eclogites, Contrib. Mineral. Petrol. 105 (1990) 550-561.

Dalton, J.A., Presnall, D.C., Carbonatitic melts along the solidus of model lherzolite in the system $\mathrm{CaO}-\mathrm{MgO}-\mathrm{Al}_{2} \mathrm{O}_{3}-\mathrm{SiO}_{2}-\mathrm{CO}_{2}$ from 3 to $7 \mathrm{GPa}$, Contrib. Mineral. Petrol. 131 (1998) 123-135.

Dasgupta, R., Hirschmann, M.M., Withers, A.C., Deep global cycling of carbon constrained by the solidus of anhydrous, carbonated eclogite under upper mantle conditions, Earth Planet. Sci. Lett. 227 (2004) 73-85.

Draper, D.S., van Westrenen W., Quantifying garnet-melt trace element partitioning using lattice-strain theory: assessment of statistically significant controls and a new predictive model, Contrib. Mineral. Petrol. 154 (2007) 731-746.

Draper, D.S., Xirouchakis, D., Agee, C.B., Trace element partitioning between garnet and chondritic melt from 5 to $9 \mathrm{GPa}$ : implications for the onset of majorite transition in the martian mantle, Phys. Earth Planet. Int. 139 (2003) 149-169. 
Eggler, D.H., The effect of $\mathrm{CO}_{2}$ upon partial melting of peridotite in the system $\mathrm{Na}_{2} \mathrm{O}-\mathrm{CaO}-$

$\mathrm{Al}_{2} \mathrm{O}_{3}-\mathrm{MgO}-\mathrm{SiO}_{2}-\mathrm{CO}_{2}$ to $35 \mathrm{~kb}$, with an analysis of melting in a peridotite- $\mathrm{H}_{2} \mathrm{O}-\mathrm{CO}_{2}$ system, Amer. J. Sci. 278 (1978) 305-434.

Falloon, T.J., Green, D.H., The solidus of carbonated, fertile peridotite, Earth Planet Sci Lett 94 (1989) 364-370.

Green, D. H., Wallace, M.E., Mantle metasomatism by ephemeral carbonatite melts, Nature 336 (1988) 459-462.

Green, T.H., Adam, J., Sie, S.H., Trace element partitioning between silicate minerals and carbonatite at $25 \mathrm{kbar}$ and application to mantle metasomatism. Mineral. Petrol 46 (1992) 179-184.

Grégoire, M., Cottin, J.Y., Mattieli, N., Giret, A. and Weis, D., The meta-igneous granulite xenoliths from Kerguelen archipelago: evidence of a continent nucleation in an oceanic setting, Contrib. Mineral. Petrol. 133 (1998) 259-283.

Hamilton, D.L., Bedson, P., Esson, J., The behaviour of trace elements in the evolution of carbonatites, In : Carbonatites, Genesis and Evolution (ed. Bell, K.) 405-427 (Unwin Hyman, London, 1989).

Hammouda, T., High pressure melting of carbonated eclogite and experimental constraints on carbon recycling and storage in the mantle, Earth Planet Sci. 214 (2003) 357-368.

Hammouda, T., Laporte, D., Ultra-fast mantle impregnation by carbonatitic melt, Geology 28 (2000) 283-285.

Harte, B., Kirkley, M.B., Partitioning of trace elements between clinopyroxene and garnet: data from mantle eclogites, Chem. Geol. 136 (1997) 1-24.

Keshav, S., Corgne, A., Gudfinnsson, G.H., Bizimis, M., McDonough, W.F. Fei, Y., Kimberlite petrogenesis; insights from clinopyroxene-melt partitioning experiments at $6 \mathrm{GPa}$ in the $\mathrm{CaO}-\mathrm{MgO}-\mathrm{Al}_{2} \mathrm{O}_{3}-\mathrm{SiO}_{2}-\mathrm{CO}_{2}$ system. Geochim. Cosmochim. Acta 69 (2005) 2829-2845.

Klemme, S., Van der Laan, S.R., Foley, S.F., Günther, D., Experimentally determined trace and minor element partitioning between clinopyroxene and carbonatite melt under upper mantle conditions, Earth and Planetary Sciences Letters 133 (1995) 439-448.

McDonough, W.F., Sun, S.S., The composition of the Earth, Chem. Geol. 120 (1995) 223253.

Morishima, H., Kato, T., Suto, M., Ohtani, E., Urakawa, S., Utsumi, W., Shimomura, O., Kikegawa, T., The phase boundary between $\alpha$ - and $\beta-\mathrm{Mg}_{2} \mathrm{SiO}_{4}$ determined by in situ X-ray observation, Science 265 (1994) 1202-1203.

Nelson, D.R., Chivas, A.R., Chappell, B.W., McCulloch, M.T., Geochemical and isotopic systematics in carbonatites and implications for the evolution if ocean-island sources, Geochim. Cosmochim. Acta 52 (1988) 1-17. 
Norman, M.D., Griffin, W.L., Pearson, N.J., Garcia M.O., O'Reilly S.Y., Quantitative analysis of trace element abundances in glasses and minerals : a comparison of laser ablation

517

518

519

520

521

522

523

524

525

526

527

528

529

530

531

532

533

534

535

536

537

538

539

540

541

542

543

544

545

546

547

548

549

550

551

552

553

554

555

556

557

558

559

560

561

562

563 inductively coupled plasma mass spectrometry, solution inductively coupled plasma mass spectrometry, proton microprobe and electron microprobe data. J. Anal. Atom. Spec., 13 (1998) 477-482.

Pertermann, M., Hirschmann, M.M., Trace-element partitioning between vacancy-rich eclogitic clinopyroxene and silicate melt, Amer. Mineral. 87 (2002) 1365-1376.

Plank, T., Langmuir, C.H., The chemical composition of subducting sediment and its consequences for the crust and mantle, Chem. Geol. 145 (1998) 325-394.

Poitrasson, F., Freydier, R., Mao, X., Mao, S.S., Russo, R.E. Femtosecond laser ablation ICPMS analysis of trace elements in solids, Geochim. Cosmochim. Acta 70 (2005) 18, A54, (Goldschmidt Conference abstract).

Shannon, R.D., Revised Effective Ionic Radii and Systematic Studies of Interatomic Distances in Halides and Chalcogenides, Acta Cryst A 32 (1976), 751-767.

Sun, S.S., McDonough, W.F., Chemical and isotopic systematics of oceanic basalts; implications for mantle composition and processes., In : Magmatism in the ocean basins, A.D. Saunders and M.J. Norry (Eds), Geological Society Special Publications 42 : 313-345, 1989.

Sweeney, R.J., Green, D.H., Sie, S.H., Trace and minor element partitioning between garnet and amphibole and carbonatitic melt. Earth Planet. Sci. Lett. 113 (1992) 1-14.

Sweeney, R.J., Prozesky, V., Przybylowicz, W., Selected trace and minor element partitioning between peridotite minerals and carbonatite melts at $18-46 \mathrm{~kb}$ pressure, Geochim. Cosmochim. Acta. 59 (1995) 3671-3683.

Van Achterberg, E., Ryan, C.G., Jackson, S., Griffin, W.L., 2001. Data reduction software for LA-ICP-MS. In: Sylvester, P. (Ed.), Laser-Ablation-ICPMS in the Earth Sciences, Principles and Applications Short Course Series-Mineralogical Association of Canada, vol. 29, pp. 239243

van Westrenen, W., Draper, D.S., Quantifying garnet-melt trace element partitioning using lattice-strain theory: new crystal-chemical and thermodynamic constraints, Contrib. Mineral. Petrol. 154 (2007) 717-730.

van Westrenen, W., Blundy, J.D., Wood, B.J., Crystal-chemical controls on trace element partitioning between garnet and anhydrous silicate melt. Amer. Mineral. 84 (1999) 838-847.

van Westrenen, W., Wood, B.J., Blundy, J.D., A predictive thermodynamic model of garnetmelt trace element partitioning, , Contrib. Mineral. Petrol.142 (2001) 219-234.

Veksler, I.V., Petibon, C., Jenner, G.A., Dorfman, A.M., Dingwell, D.B., Trace element partitiong in immiscible silicate-carbonate liquid systems : an initial experimental study using a centrifuge autoclave, J. Petrol 39 (1998) 2095-2014. 
564 Walker, D., Carpenter, M.A., Hitch, C.M., Some simplifications to multianvil devices for 565 high pressure experiments, Amer. Mineral. 75 (1990) 1020-1028.

Wallace, M.E., Green, D.H., An experimental determination of primary carbonatite magma composition, Nature 335 (1988) 343-346.

Watson, E.B., Brenan, J.M., Baker, D.R., Distribution of fluids in the continental mantle, in, M.A. Menzies (Ed), Continental mantle, Oxford Science Publications, Clarendon Press, Oxford, 1990, pp. 111-125.

Wendlandt, R.F., Harrison, W.J., Rare earth partitioning between immiscible carbonate and silicate liquids and $\mathrm{CO}_{2}$ vapor : results and implications for the formation of light rare earthenriched rocks, Contrib. Mineral. Petrol. 69 (1979) 409-419.

White, B.S., Wyllie, P.J., Solidus reactions in synthetic lherzolite- $\mathrm{H}_{2} \mathrm{O}-\mathrm{CO}_{2}$ from 20-30 kbar, with applications to melting and metasomatism, J. Volcanol. Geotherm. Res. 50 (1992) $117-$ 130.

Wood, B.J., Blundy, J.D., The effect of cation charge on crystal-melt partitioning of trace elements, Earth Planet. Sci. Lett. 188 (2001) 59-71.

Wood, B.J., Blundy, J.D., A predictive model for rare earth element partitioning between clinopyroxene and anhydrous silicate melt. Contrib. Mineral. Petrol. 129 (1997) 166-181.

Wooley, A.R., Kempe, D.R.C., Carbonatites : nomenclature, average chemical compositions, and element distribution. in Carbonatites, Genesis and Evolution (ed. Bell, K.) 1-14 (Unwin Hyman, London, 1989).

Wyllie, P.J., Huang, W.-L., Carbonation and melting reactions in the system $\mathrm{CaO}-\mathrm{MgO}-\mathrm{SiO}_{2}-$ $\mathrm{CO}_{2}$ at mantle pressures with geophysical and petrological applications, Contrib. Mineral. Petrol. 54 (1976) 79-107.

Yaxley, G.M., Brey, G.P., Phase relations of carbonate-bearing eclogite assemblages from 2.5 to $5.5 \mathrm{GPa}$ : implications for petrogenesis of carbonatites, Contrib. Mineral. Petrol. 146 (2004) 606-619. 
List of tables

Table 1 : Details on experimental run conditions and resulting phase assemblages and phase proportions.

Table 2 : Electron probe analyses of run products.

Table 3 : Site filling for clinopyroxenes and garnets from Table 2. All iron was assumed to be in the form $\mathrm{Fe}^{2+}$. For clinopyroxene, satured M1 octahedral site was considered and all vacancies were assigned to M2 site.

Table 4 : Trace element concentrations and resulting partition coefficients. Number in brackets indicate the uncertainty ( 1 sigma) on the last reported digits; $n$ is the number of analyses in each phase.

Table 5 : Mass balance on trace elements in experiments 273 and 274.

Table 6 : Parameters obtained using the lattice strain model for trivalent cations in clinopyroxene and garnet. Top : fit on the experimental data on $\mathrm{La}, \mathrm{Gd}, \mathrm{Yb}$. Bottom : calculated parameters using predictive model of Wood and Blundy (1997) for cpx and van Westrenen and Draper (2007, $D_{0}$ thermodynamical) and Draper and van Westrenen $\left(2007, D_{0}\right.$ statistical) for garnet. 
Table 1

Details on experimental run conditions and resulting phase assemblages and phase proportions.

\begin{tabular}{lccclccccc}
\hline Run\# & $\mathrm{P}(\mathrm{GPa})$ & $\mathrm{T}\left({ }^{\circ} \mathrm{C}\right)$ & $\mathrm{t}(\mathrm{h})$ & Result & gt & $\mathrm{cpx}$ & coes & melt & $\Sigma$ sq. res. \\
& & & & & & & & & \\
258 & 4.5 & 1300 & 20 & gt-cpx-sil melt & & & & & \\
259 & 5.0 & 1300 & 20 & gt-cpx-sil melt & & & & \\
273 & 6.0 & 1300 & 20 & gt-cpx-coes-sil melt & 23.76 & 44.58 & 2.23 & 27.78 & 1.415 \\
274 & 7.0 & 1300 & 20 & gt-cpx-coes-carb melt & 35.06 & 47.13 & 6.62 & 10.25 & 0.306 \\
\hline
\end{tabular}


Table 2

Major element composition of selected phases in experimental assemblages. (n.a., not analyzed.)

\begin{tabular}{|c|c|c|c|c|c|c|c|c|}
\hline Oxide (wt \%) & $\mathrm{SiO}_{2}$ & $\mathrm{Al}_{2} \mathrm{O}_{3}$ & $\mathrm{FeO}$ & $\mathrm{MgO}$ & $\mathrm{CaO}$ & $\mathrm{Na}_{2} \mathrm{O}$ & $\mathrm{K}_{2} \mathrm{O}$ & Total \\
\hline \multicolumn{9}{|c|}{ ME258 (4.5 Gpa - $\left.1300^{\circ} \mathrm{C}\right)$} \\
\hline CPX & 51.1081 & 16.1666 & 8.882 & 6.5218 & 14.1514 & 3.4629 & n.a. & 100.3045 \\
\hline GARNET & 39.822 & 22.2105 & 18.1422 & 8.1454 & 12.579 & 0.0383 & 0.0151 & 100.9525 \\
\hline MELT & 51.2436 & 15.0045 & 7.6117 & 3.1035 & 13.0825 & 2.2664 & 0.1731 & 92.4854 \\
\hline \multicolumn{9}{|c|}{ ME259 ( 5 Gpa- $1300^{\circ} \mathrm{C}$ ) } \\
\hline CPX & 50.8388 & 15.333 & 7.732 & 6.9036 & 15.4316 & 3.5306 & n.a. & 99.7696 \\
\hline GARNET & 39.317 & 22.0813 & 18.2679 & 8.161 & 12.0877 & 0.0688 & 0.0242 & 100.0079 \\
\hline MELT & 47.9129 & 13.8499 & 8.9488 & 3.0546 & 14.5676 & 2.0411 & 0.1983 & 90.5732 \\
\hline \multicolumn{9}{|c|}{ ME273 (6 Gpa $\left.-1300^{\circ} \mathrm{C}\right)$} \\
\hline CPX & 52.716 & 17.598 & 5.565 & 6.5 & 13.27 & 4.196 & n.a. & 99.857 \\
\hline GARNET & 39.168 & 22.195 & 15.111 & 8.731 & 13.62 & 0.109 & n.a. & 98.938 \\
\hline MELT & 39.78 & 10.193 & 9.324 & 3.127 & 18.247 & 1.658 & 0.118 & 82.45 \\
\hline \multicolumn{9}{|c|}{ ME274 ( $\left.7 \mathrm{Gpa}-1300^{\circ} \mathrm{C}\right)$} \\
\hline CPX & 54.494 & 15.607 & 5.981 & 6.702 & 12.651 & 5.49 & n.a. & 100.929 \\
\hline GARNET & 40.065 & 21.81 & 15.282 & 9.017 & 13.709 & 0.125 & 0.035 & 100.046 \\
\hline MELT & 0.086 & 0.161 & 7.236 & 4.555 & 40.67 & 0.472 & 0.066 & 53.246 \\
\hline
\end{tabular}


Table 3

Structural formulae and site filling for clinopyroxenes and garnets from Table 2 . All iron was assumed to be in the form Fe ${ }^{2+}$

For clinopyroxene, satured M1 octahedral site was considered and all vacancies were assigned to M2 site.

\begin{tabular}{|c|c|c|c|c|c|c|c|c|c|}
\hline CPX & ME258 & ME259 & ME273 & ME274 & GARNET & ME258 & ME259 & ME273 & ME274 \\
\hline$P(G P a)$ & 4.5 & 5 & 6 & 7 & $P(G P a)$ & 4.5 & 5 & 6 & 7 \\
\hline $\mathrm{T}\left({ }^{\circ} \mathrm{C}\right)$ & 1300 & 1300 & 1300 & 1300 & $\mathrm{~T}\left({ }^{\circ} \mathrm{C}\right)$ & 1300 & 1300 & 1300 & 1300 \\
\hline $\mathrm{Si}$ & 1.842 & 1.843 & 1.870 & 1.918 & $\mathrm{Si}$ & 2.991 & 2.983 & 2.976 & 3.010 \\
\hline \multirow[t]{2}{*}{ All V } & 0.158 & 0.157 & 0.130 & 0.082 & Al & 1.967 & 1.975 & 1.988 & 1.931 \\
\hline & & & & & $\mathrm{Fe}$ & 1.140 & 1.159 & 0.960 & 0.960 \\
\hline M1 & & & & & $\mathrm{Mg}$ & 0.912 & 0.923 & 0.989 & 1.009 \\
\hline AIVI & 0.529 & 0.498 & 0.605 & 0.566 & $\mathrm{Ca}$ & 1.012 & 0.983 & 1.109 & 1.103 \\
\hline $\mathrm{Mg}$ & 0.350 & 0.373 & 0.344 & 0.352 & $\mathrm{Na}$ & 0.006 & 0.010 & 0.016 & 0.018 \\
\hline \multirow[t]{2}{*}{$\mathrm{Fe}$} & 0.121 & 0.129 & 0.051 & 0.083 & K & 0.001 & 0.002 & 0.000 & 0.003 \\
\hline & & & & & sum cations & 8.029 & 8.036 & 8.038 & 8.035 \\
\hline \multicolumn{10}{|l|}{ M2 } \\
\hline $\mathrm{Ca}$ & 0.547 & 0.599 & 0.504 & 0.477 & $\mathrm{Ca} \%$ & 33.04 & 32.07 & 36.26 & 35.91 \\
\hline $\mathrm{Na}$ & 0.242 & 0.248 & 0.289 & 0.375 & $\mathrm{Mg} \%$ & 29.76 & 30.11 & 32.33 & 32.85 \\
\hline $\mathrm{Fe}$ & 0.147 & 0.106 & 0.114 & 0.093 & $\mathrm{Fe} \%$ & 37.20 & 37.82 & 31.40 & 31.24 \\
\hline $\mathrm{Mg}$ & 0.000 & 0.000 & 0.000 & 0.000 & $\mathrm{Mg} \#$ & 44.45 & 44.32 & 50.73 & 51.25 \\
\hline sum cations & 3.936 & 3.953 & 3.907 & 3.945 & & & & & \\
\hline vac & 0.064 & 0.047 & 0.093 & 0.055 & & & & & \\
\hline Mg\# & 56.68 & 61.41 & 67.55 & 66.63 & & & & & \\
\hline
\end{tabular}


Table 4

Trace element concentrations (in ppm) and resulting partition coefficients. Number in brackets indicate the uncertainty ( 1 sigma) on the last reported digits; $n$ is the number of analyses in each phase.

\section{By electron microprobe}

\section{Concentrations}

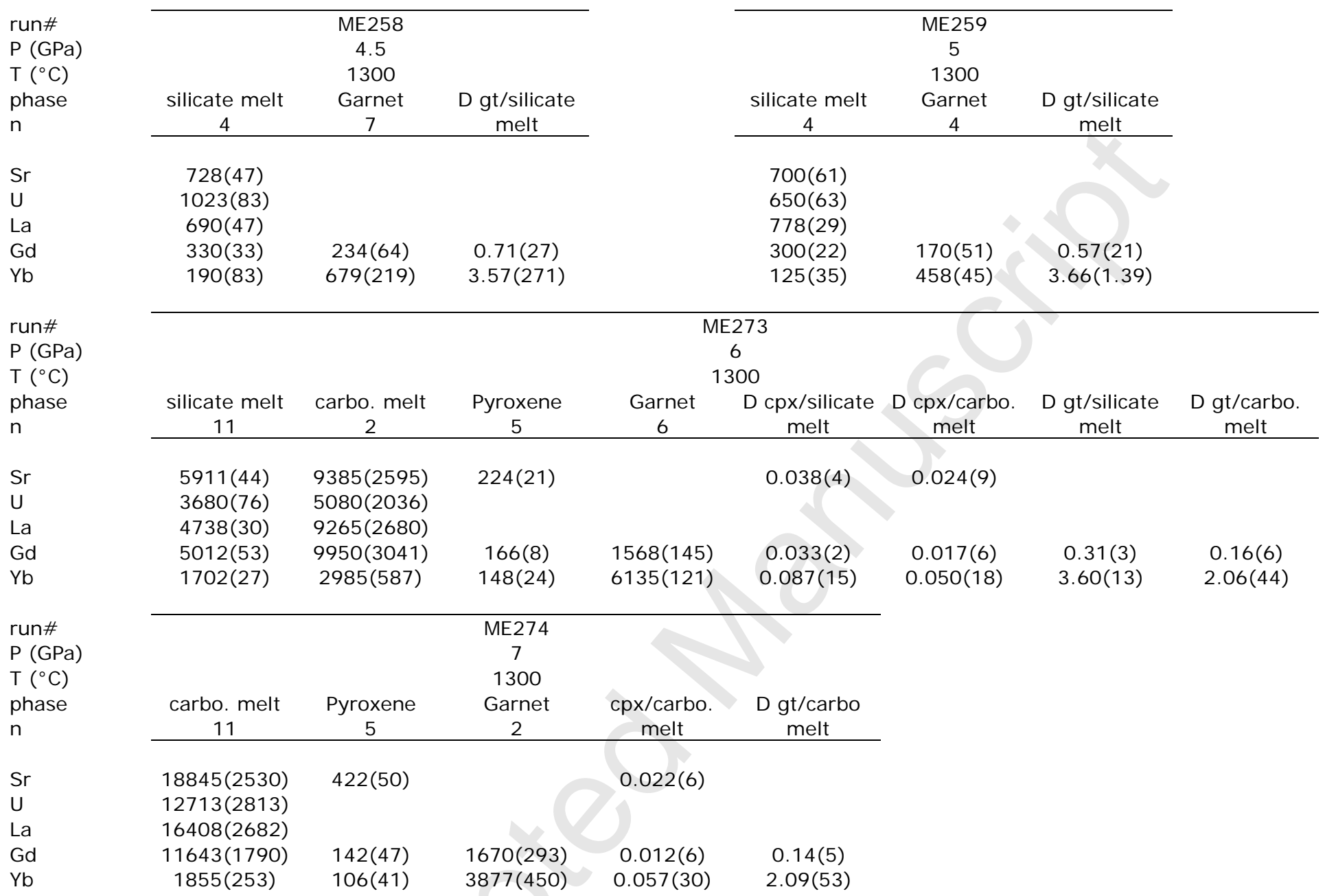

\section{By laser ablation ICP-MS - sample ME273}

\section{Concentrations}

n

$\mathrm{n}$ $\begin{array}{ccc}\text { silicate melt } & \text { pyroxene } & \text { garnet } \\ 3 & 3 & 2\end{array}$

$\mathrm{Sr}$

U

La

$\mathrm{Gd}$

$\underline{\mathrm{Yb}}$

\begin{tabular}{ccc}
3 & 3 & 2 \\
\hline & & \\
$6320(152)$ & $137(10)$ & $15.3(27)$ \\
$5475(252)$ & 1.7 & $18.7(2)$ \\
$5221(44)$ & $9.1(1)$ & $6(1)$ \\
$6361(180)$ & $189(1)$ & $2033(55)$ \\
$2459(43)$ & $205(12)$ & $8355(134)$
\end{tabular}

Partition coefficients - sample ME273

\begin{tabular}{ccc} 
D cpx/melt & D gt/melt & D cpx/gt \\
\hline $0.022(2)$ & $0.0024(5)$ & $9.0(2.2)$ \\
$0.00031(2)$ & $0.0034(2)$ & $0.091(1)$ \\
$0.00175(3)$ & $0.0012(3)$ & $1.51(33)$ \\
$0.030(1)$ & $0.32(2)$ & $0.093(3)$ \\
$0.083(6)$ & $3.4(1)$ & $0.024(2)$
\end{tabular}


Table 5

Mass balance calculations on experimental samples.

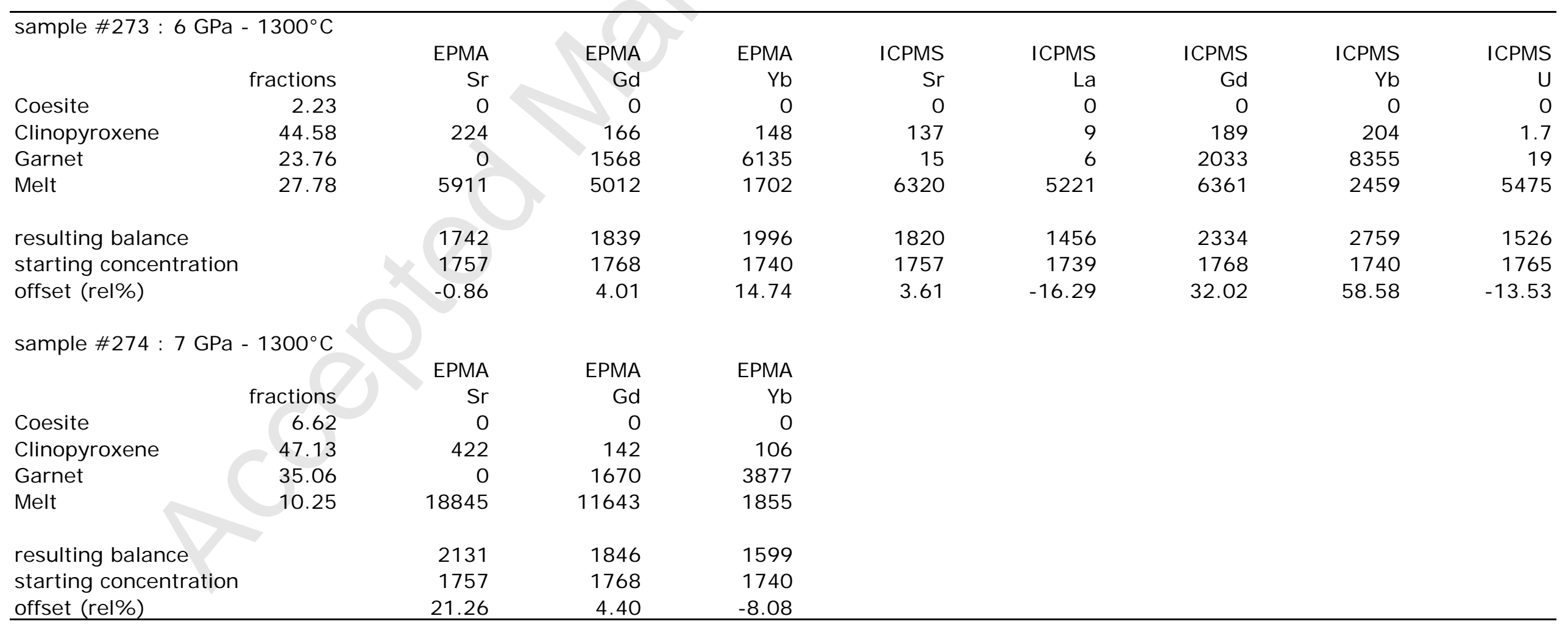


Table 6

Parameters obtained using the lattice strain model for trivalent cations in clinopyroxene and garnet. Top : fit on the experimental data on La, Gd, Yb. Bottom : calculated parameters using predictive model of Wood and Blundy (1997) for $\mathrm{cpx}$ and van Westrenen and Draper (2007, $\mathrm{D}_{0}$ thermodynamical) and Draper and van Westrenen $\left(2007, D_{0}\right.$ statistical) for garnet.

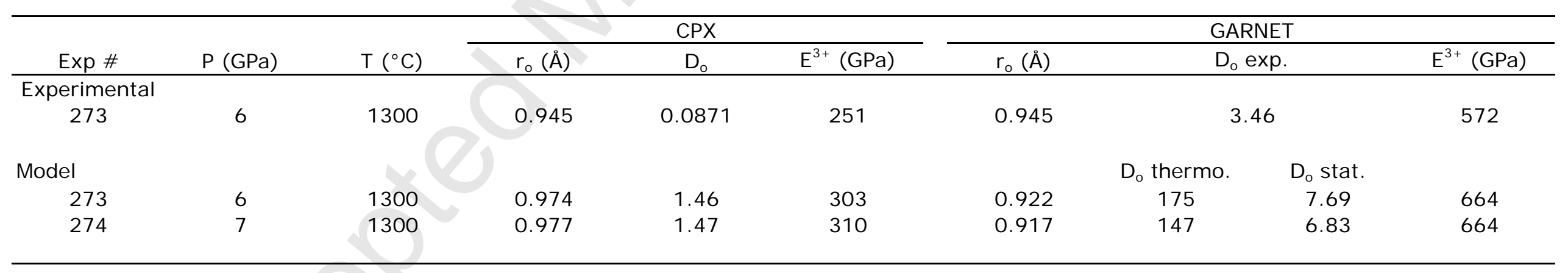


Figure captions

Figure 1: (a) Backscattered electron micrograph of run products showing coesite needles (darkest gray), Na-rich clinopyroxene (dark gray), garnet (lightest gray) in glassy matrix. (b) Close-up view of the region shown in (a) illustrating the size of the craters due to laser ablation.

Figure 2: Obtained partition coefficients and comparison with literature data (references used are given in the text).

Figure 3: Comparison between experimentally obtained partition coefficient values and values predicted using lattice strain modeling. Ionic radii are those of Shannon (1976). (3a) Clinopyroxenes : experimental data (exp.) are compared to predictions (pred.) using Wood and Blundy (1997). In addition to data obtained in the present investigation, references used are AG, Adam and Green (2001) ; K, Keshav et al. (2005) ; PH, Pertermann and Hirschmann (2002). (3b) Garnets: experimental data (exp.) are compared to predictions using the statistical approach (pred. stat) of Draper and van Westrenen (2007) and the thermodynamic approach (pred. thermo) of van Westrenen and Draper (2007). See text for further discussion.

Figure 4 : Partition coefficient values for $\mathrm{Gd}$ and $\mathrm{Yb}$ in garnet as a function of pressure.

Figure 5 : Modeling of REE spectra associated to mantle metasomatism due to melting of MORB + carbonate mixtures. All spectra are normalized relative to primitive mantle (McDonough and Sun, 1995). (5a) Modeled REE spectra of a source composed of 0.9 MORB +0.1 carbonated sediments as used in the experiments and liquids produced by $10 \mathrm{wt} \%$ 
melting degree (batch melting) at 6 and $7 \mathrm{GPa}$ (5b) Modeled REE spectra of a lherzolitic mantle after interaction with carbonatitic melts produced at $7 \mathrm{GPa}$. Two case have been considered : simple adjunction of $1 \mathrm{wt} \%$ melt (10 wt $\%$ melting degree) to mantle; melt mantle equilibration wherein the mantle portion is impregnated by an interconnected melt network (also produced by $10 \mathrm{wt} \%$ melting degree). In the latter case, partition coefficients used where those of Blundy and Dalton (2000) for clinopyroxene and Adam and Green (2001) for garnet. Both melt type are used in the models detailed in the next panel. (5c) Modeled REE spectra for melting of a metasomatized mantle portion and comparison with low degree melting of fertile pyrolite. The following cases are illustrated: (ם) $1.5 \mathrm{wt} \%$ melting of pyrolite with $1 \mathrm{wt} \%$ carbonatite melt added ; $(\mathbf{\Delta}) 0.5 \mathrm{wt} \%$ melting of pyrolite with 1 wt\% carbonatite melt added; (O) $1.5 \mathrm{wt} \%$ melting of pyrolite equilibrated with interconnected carbonatitic melt network treated as an infinite reservoir ; $(\Delta) 1.5 \mathrm{wt} \%$ melting of pyrolite. All models assume batch melting. 

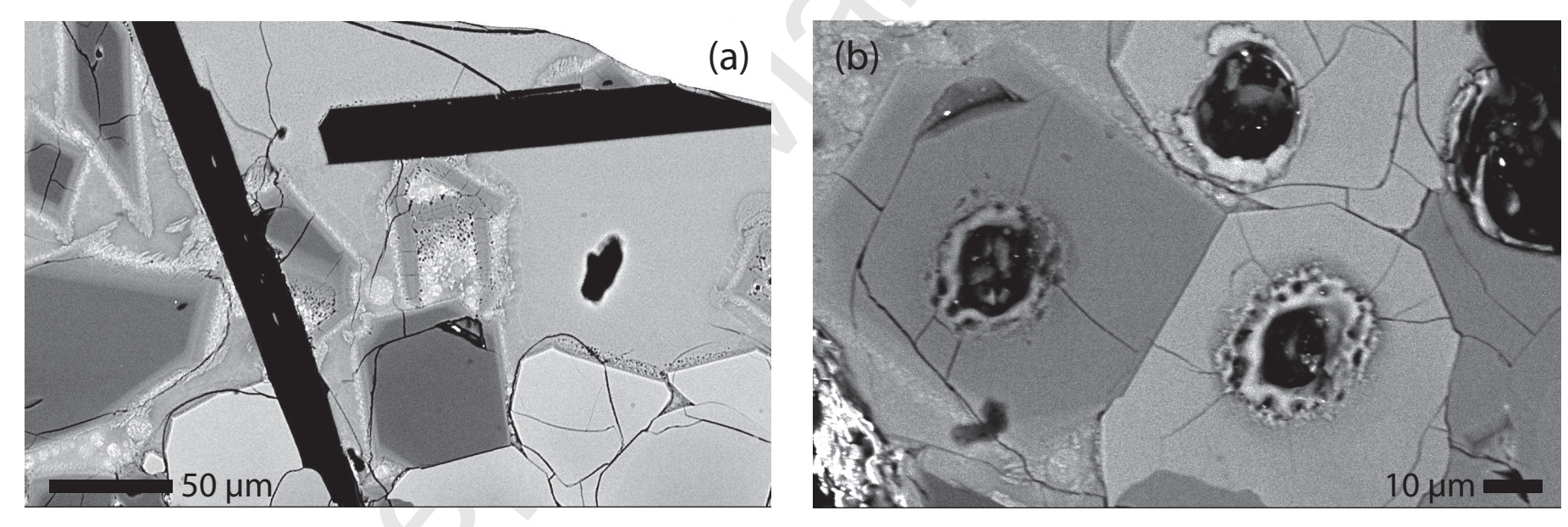

FIGURE 1 

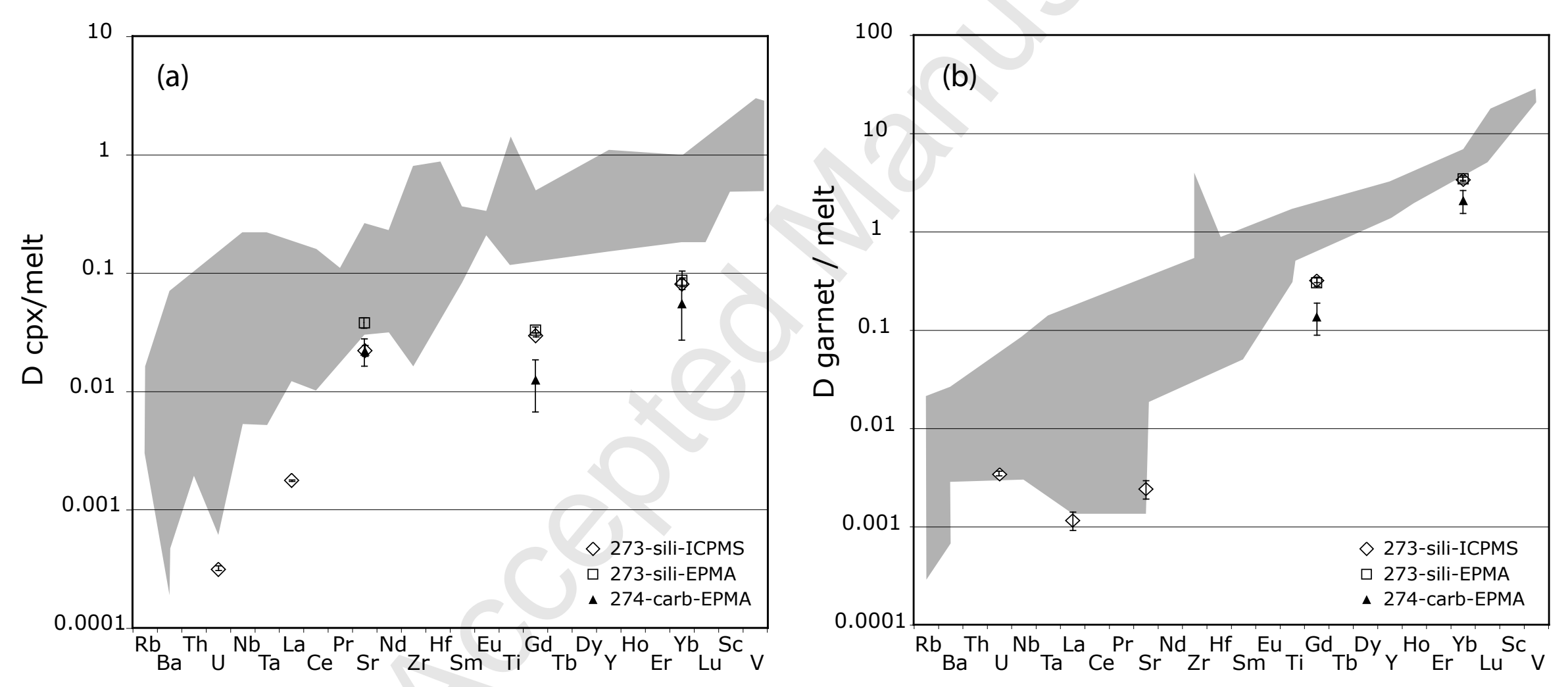

FIGURE 2 

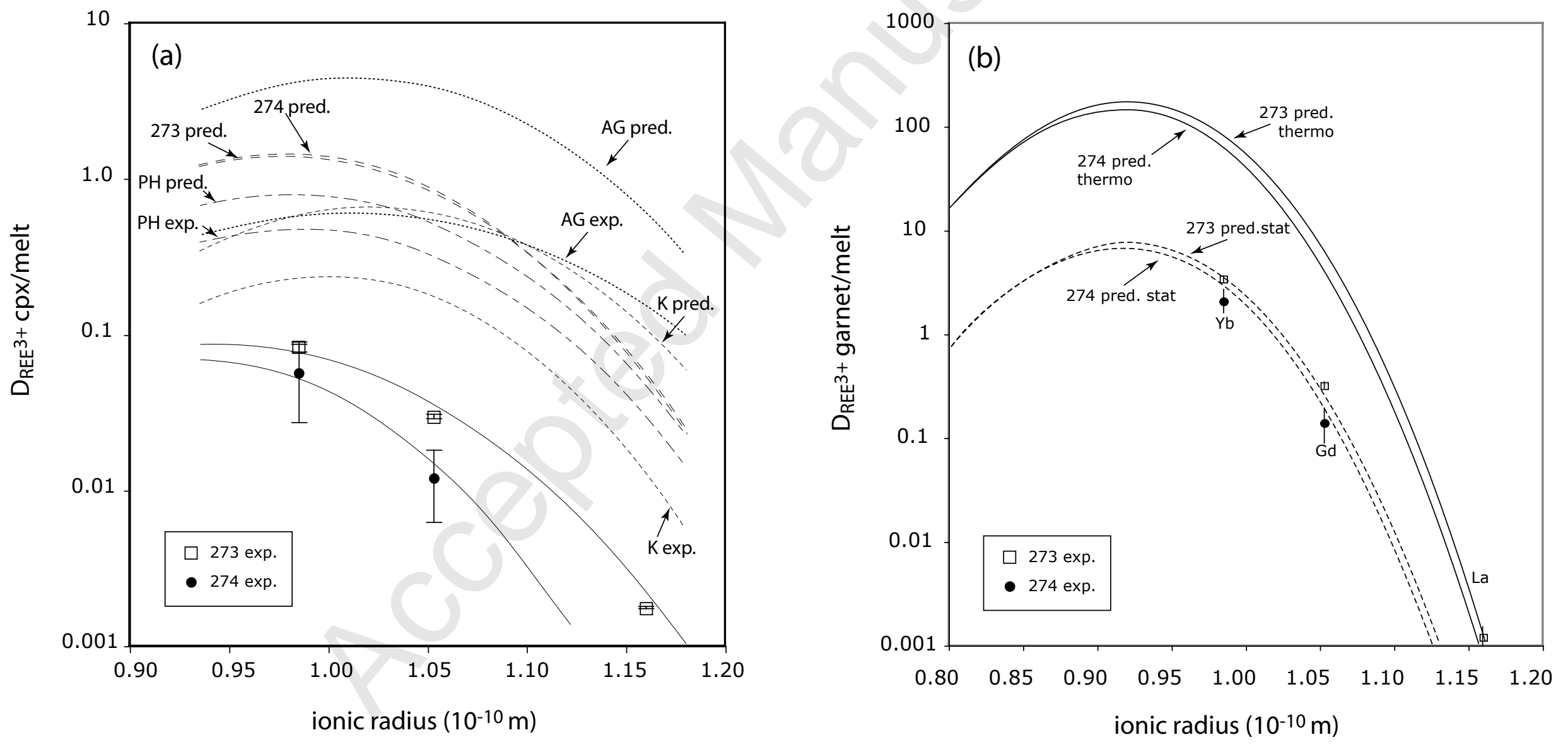

FIGURE 3 


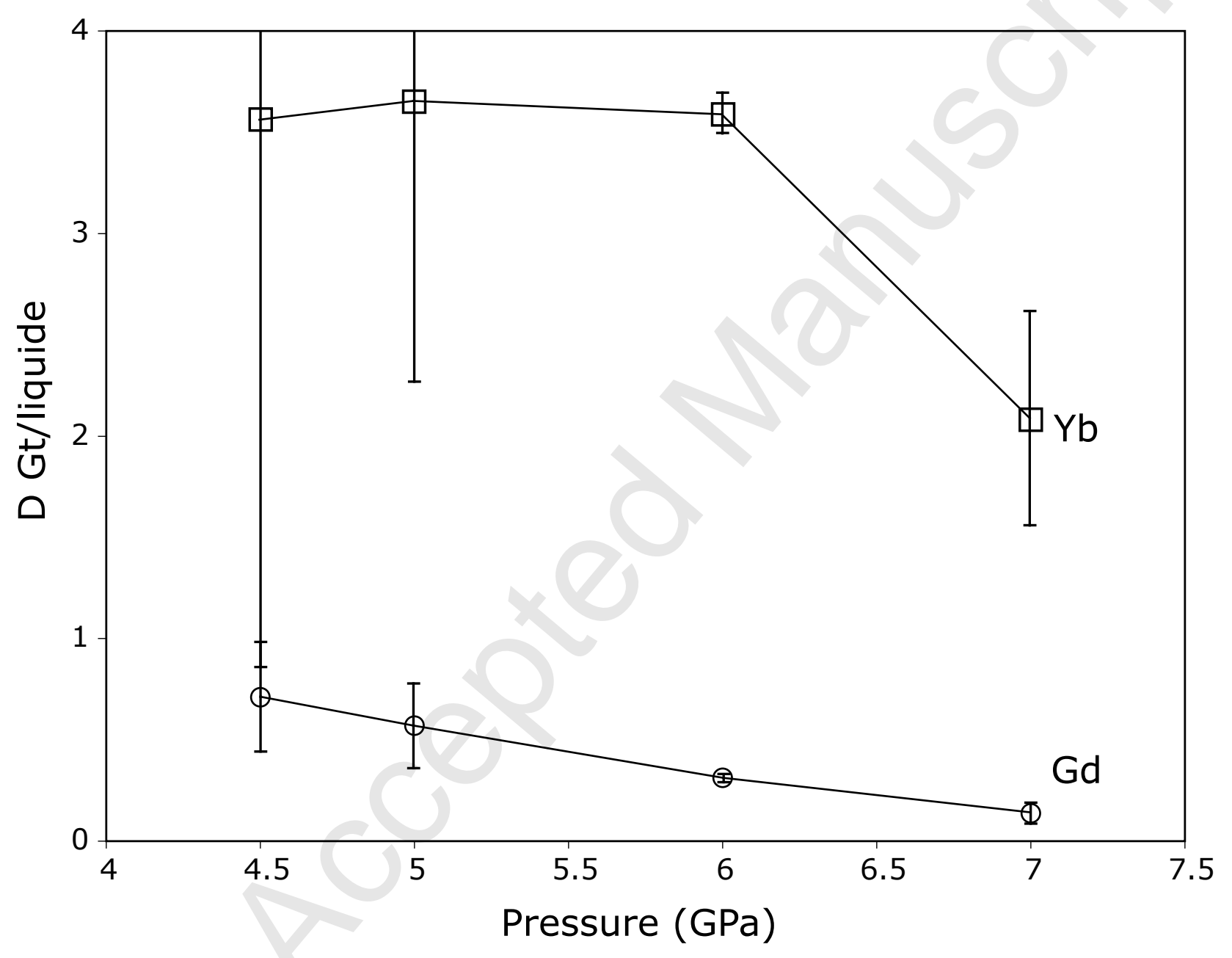

FIGURE 4 

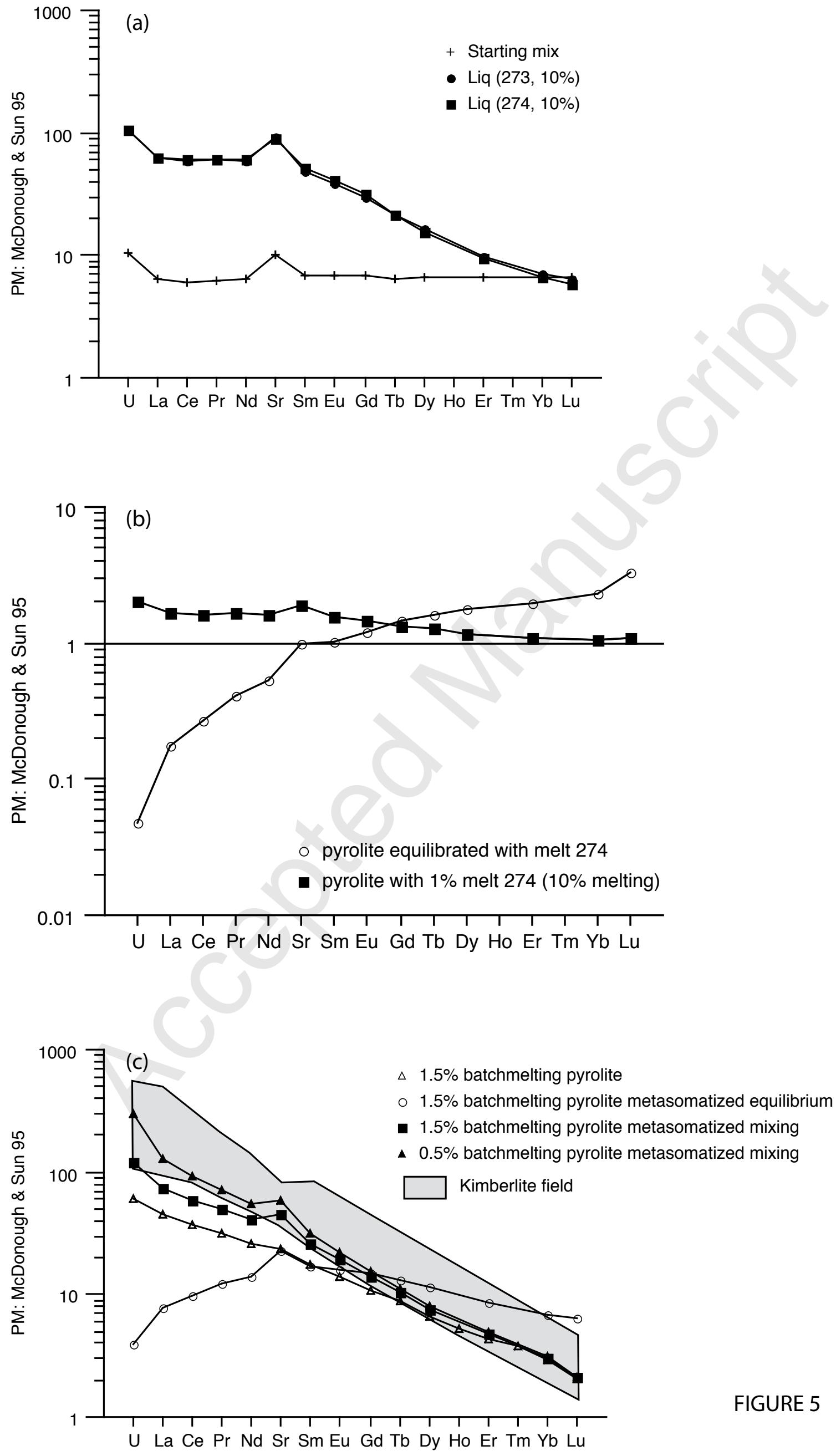